Sains Malaysiana 50(10)(2021): 2885-2898

http://doi.org/10.17576/jsm-2021-5010-04

\title{
The Diet of a Roosting Population of Asian Glossy Starling Aplonis panayensis in Jelebu, Negeri Sembilan, Malaysia
}

(Diet bagi Populasi Bermalam Perling Mata Merah Aplonis panayensis di Jelebu, Negeri Sembilan, Malaysia)

\section{Noorul Ezyan Nor Hashim, Mohammad Saiful Mansor, Nurul Ashikin Abdullah \& Rosli RamLi*}

\begin{abstract}
Communal roosting by urban birds, such as crows, mynas, and starlings, can be a public nuisance due to excessive noise and fouling of the surroundings with droppings. Food availability within proximity to the roosting area is one of the key factors influencing roosting site preference and fidelity. The diets of roosting mynas and crows have been wellstudied, yet little is known about the diet of the Asian glossy starling (AGS), Aplonis panayensis. This study focused on assessing the diet of roosting AGS and food resource availability around the roosting area. The AGS diet was assessed through microscopic analysis of stomach contents and droppings. The diet mainly consisted of fruits (76\%) with a minor component of animal materials, i.e. ants, snails, and beetle larvae. Intact seeds found in the samples were identified using DNA barcoding. Seven out of the nine plant species detected were new records for the AGS diet. The most common fruit found in the samples was Trema orientalis, which grows extensively along roadsides within foraging areas of AGS. The availability of fruits of different fast-growing pioneer species around the roosting site ensured a continuous supply of food to the birds. Animal materials, which were consumed by chance during foraging, supplemented the fruit in the bird's diet. Hence, the birds'preference for the roosting site may have been influenced by the availability of various food resources around it.
\end{abstract}

Keywords: Dietary variation; DNA barcoding; pest bird; roosting; starlings

ABSTRAK

Bermalam secara berkumpulan oleh burung bandar seperti gagak, tiong dan perling boleh mengganggu orang awam dengan bunyi bising dan mencemarkan persekitaran dengan najis burung. Sumber makanan yang banyak di sekitar kawasan bermalam menjadi satu faktor penarik kepada burung untuk bermalam di sesuatu kawasan. Kajian diet burung gagak dan tiong bermalam telah banyak dilakukan tetapi hanya sedikit maklumat pemakanan Perling Mata Merah Aplonis panayensis yang dikaji. Kajian ini menumpukan kepada penilaian diet Perling Mata Merah yang bermalam di kawasan kajian untuk mengenal pasti sumber makanan yang ada di sekitarnya. Penilaian diet burung ini dilakukan melalui analisis mikroskopik kandungan perut dan najis. Diet utama Perling Mata Merah adalah buahbuahan (76\%) di samping sejumlah kecil kandungan haiwan seperti semut, siput dan larva kumbang. Pengecaman lanjut biji benih buah yang dijumpai di dalam sampel diet dilakukan melalui teknik pengekodan DNA. Daripada sembilan spesies tumbuhan yang dikenal pasti, tujuh spesies merupakan rekod baharu untuk diet Perling Mata Merah. Buah daripada pokok Trema orientalis adalah yang paling banyak dijumpai di dalam diet dan tumbuhan ini didapati tumbuh secara meluas di pinggir jalan dalam jarak pencarian makanan oleh Perling Mata Merah. Pokok-pokok perintis ini mempunyai pertumbuhan yang cepat dan menghasilkan sumber buah-buahan yang banyak kepada Perling Mata Merah. Sumber haiwan yang diambil secara kebetulan oleh Perling Mata Merah semasa memakan buah adalah diet tambahan kepada burung ini. Oleh itu, pemilihan kawasan bermalam oleh Perling Mata Merah boleh dipengaruhi oleh ketersediaan pelbagai sumber makanan di sekitar kawasan tersebut.

Kata kunci: Bermalam; burung perosak; perling; pengekodan DNA; variasi diet

\section{INTRODUCTION}

The Asian glossy starling (AGS), Aplonis panayensis, is a gregarious species that flocks together in large groups for feeding and roosts communally at night. It is commonly found near human habitation like cities, gardens, plantations, and parks (Sontag \& Loutte 2007; Strange \& 
Jeyarajasingam 1993); and is associated with buildings and areas offering tall trees and abundant fruit supplies (Robson 2008; Wells 2007). AGS roosts together with flocks of invasive birds such as the house crow Corvus splendens, common myna Acridotheres tristis, and Javan myna Acridotheres javanicus (Jeyarajasingam \& Pearson 2012; Peh \& Sodhi 2002; Yap et al. 2002; Wells 2007).

Urban roost sites can cause noise pollution, while the droppings damage buildings and cars, foul walkways, and pollute reservoirs (Yap et al. 2002). In some European cities, excrement from European starlings contain spores of Histoplasma capsulatum, which can cause severe respiratory disease in humans (Thiele et al. 2012). Due to the impact of such roosts, extensive studies have been conducted, including recording the diet of these roosting urban birds (Brook et al. 2003; Lim et al. 2003; Soh et al. 2002; Yap \& Sodhi 2004; Yap et al. 2002; Wilson et al. 2015). However, no studies to date provide a detailed analysis of the diet of roosting AGS.

Understanding the roosting ecology of urban birds is crucial for identifying factors attracting them to particular sites, especially those near human habitation. Communal roosting can benefit the birds by increasing their foraging efficiency if the roost serves as an information center for food resources that are patchy or hard to find (Feare 1984; Ward \& Zahavi 1973). Unsuccessful foragers may receive information on better feeding grounds by following successful birds the next morning on leaving the roost (Ward \& Zahavi 1973; Weatherhead 1983). In return, dominant birds may benefit from protection against predators as a result of the increased number of birds roosting together (Weatherhead 1983). Food availability in the areas surrounding the roosting sites could affect the number of roosting birds and their site fidelity (Fischl \& Caccamise 1987; Morrison \& Caccamise 1985; Summers \& Feare 1995).

In temperate regions, the population size of European starling during roosting may vary depending on the seasonal variation in food resources (Fischl \& Caccamise 1987). The birds may change roosting sites depending on the availability of food close to the sites (Fischl \& Caccamise 1987; Morrison \& Caccamise 1985; Summers \& Feare 1995). The European starling travels a considerable distance (up to 80 kilometers) to find high-quality food, especially when food resources decline during winter or dominant birds fully occupy the nearby roosting sites (Feare 1984; Summers \& Feare 1995). Selection of nearby feeding areas along the way to the roosting site could reduce daily travel costs for starlings or else roosting sites might be changed (Fischl \& Caccamise 1987).

Most species in the genus Aplonis are frugivores, but they may also include insects in their diet (Feare 1984; Feare \& Craig 1999). AGS is known to eat a wide variety of fruits such as figs Ficus spp., soft fruits like banana and papaya, berries of Endospermum moluccensis, Campnospermum auriculatum, and Fagraea fragrans, nuts of palm trees Ptychosperma macarthurii and Caryota mitis, and pod fruits of Acacia spp. (Feare 1984; Jeyarajasingam \& Pearson 2012; Wells 2007). This species also consumes swarming termites and Hemiplecta snails (Shazali et al. 2016; Wells 2007). Dietary study of roosting birds provides a better indication of food preferences and feeding grounds within the range of preferred roosting sites. Such information is useful for formulating better management practices to control or eliminate roosting sites of pest bird species, thus reducing the negative impacts. In addition, local councils can eliminate food resources of the pest birds, especially in residential areas or cities, to control their populations (Linz et al. 2018; Teng et al. 2012).

In this study, we assessed the diet of AGS through microscopic analysis of stomach contents and droppings. However, the identification of plant materials using this technique can be challenging, depending on the condition of the material, and requires extensive botanical knowledge (Aziz et al. 2017, 2015; Galimberti et al. 2016; LaFleur et al. 2009). Fragmented plant materials, especially from frugivorous birds, can be much degraded depending on feeding style (LaFleur et al. 2009). Therefore, we used a DNA barcoding approach to identify plant materials found in the diet of AGS. This method can be used to identify species composition in complex or degraded biological mixtures (Galimberti et al. 2016; Kress et al. 2015; Mansor et al. 2018a).

\section{MATERIALS AND METHODS}

\section{STUDY AREA}

This study was conducted at the Universiti Malaya Biotechnology Research Centre in Glami Lemi (PPBGL), Jelebu, Negeri Sembilan, Malaysia ( $3^{\circ} 03$ ' 16.6" N; $102^{\circ} 03^{\prime} 50.3^{\prime \prime} \mathrm{E}$; Figure 1). The research center is located approximately $50 \mathrm{~km}$ from Seremban, Negeri Sembilan, Malaysia, and $90 \mathrm{~km}$ from Kuala Lumpur, Malaysia. The study area is about 150 acres in size, and is located adjacent to the Kenaboi Forest Reserve, surrounded by oil palm and rubber plantations, and rural areas. The 
study area was divided into three sectors, i.e., vegetation areas, farms, and research center. More AGS (>2000 birds) were seen roosting on buildings at the research center, which was referred to as the roosting area, than in other sectors.

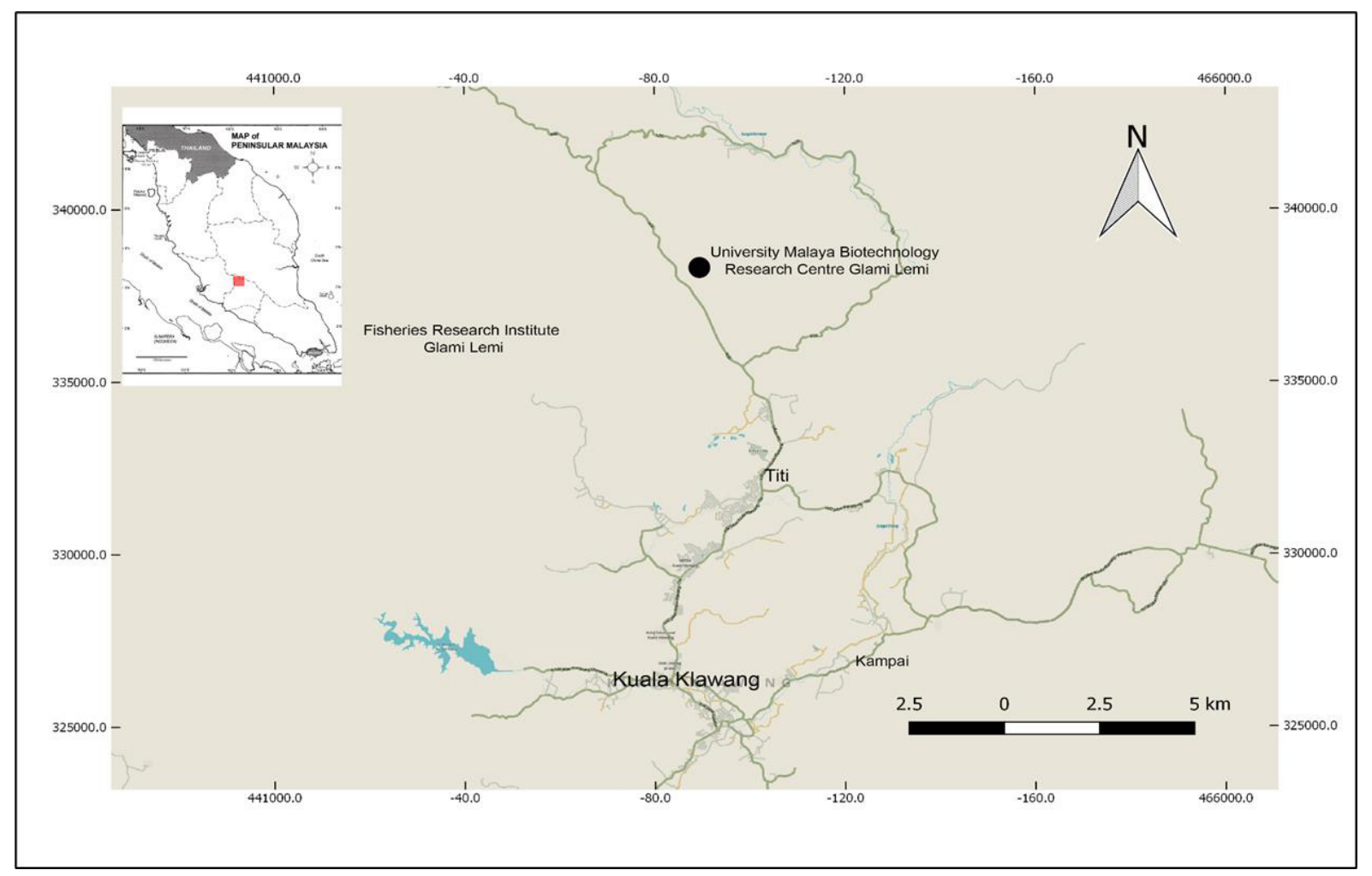

FIGURE 1. Map of Peninsular Malaysia showing the location of the study site, Universiti Malaya Biotechnology Research Centre, Glami Lemi, Jelebu, Negeri Sembilan, Malaysia (black circle)

\section{SAMPLE COLLECTION}

We extracted stomach content samples from 34 individual AGSs that were captured using mist nets. Five mist nets were set up randomly at the roosting sites during the roost entry period (19:00 - 20:00 h) on March 30 and April 26, 2016. We followed the protocols for capturing birds approved by the Institutional Animal Care and Use Committee (IACUC), Universiti Malaya, Kuala Lumpur, Malaysia (approval permit number $\mathrm{S} / 15102018 / 31082018-02 / \mathrm{R})$. We anesthetized and euthanized the captured birds following the policy and protocols approved by the IACUC, Universiti Malaya. The stomach was dissected, and the contents were extracted for further stereomicroscopic analysis.

Fresh droppings of AGS were collected noninvasively once a month from July 2016 until April
2017 during the roosting period (19:00 - 20:00 h). A transparent plastic sheet $(2 \times 2 \mathrm{~m})$ was placed under two accessible roosting sites before AGS began to enter the roost. A minimum of 10 droppings were collected at every sampling to represent different birds in one roosting site. The droppings were picked from different spots in the focal site to reduce the risk of biased sampling of droppings from the same individual. The variety of droppings was selected based on differences in texture and color to represent variation in the AGS diet in each sample. Sterilized tweezers and spatulas were used to collect fresh droppings 30 minutes after birds had started entering the roost. Both samples (stomach contents and droppings) were preserved in $99 \%$ ethanol and stored in a $-20{ }^{\circ} \mathrm{C}$ freezer for further analysis (Lim et al. 2017; Mansor et al. 2018a). 


\section{STEREOMICROSCOPIC ANALYSIS}

The samples were manually sorted in Petri dishes and divided into two categories, animal and plant materials, using a stereomicroscope. The materials were classified into different categories based on morphological characteristics. Before storage, the materials were photographed and counted for calculating percentages following the methods described by Galimberti et al. (2016) and Rodway and Cooke (2002). Animal materials (AM) were classified into different groups of invertebrates based on fragments: Ants (heads, mandibles, thorax, petiole, and wing fragments), beetles (elytra, mandibles, leg fragments, and larvae) (Mansor et al. 2018b), and shells of snails (Foon et al. 2017). Plant materials were sorted into two categories; intact seeds (IS) and fragmented plant materials (FPM), such as fruit skin, fibers, and pulp (Galimberti et al. 2016). The IS were then assigned to different seed groups based on morphological characteristics, such as seed dimensions, form, color, and surface texture. The animal and plant materials were identified to family or genus level (if possible) with the aid of references (Foon et al. 2017; Hashimoto 2003; Ng 1991; Ng et al. 2015) and experts. The identification was also aided by a list of potential food resources of AGS gathered from habitat surveys, secondary information (Jeyarasingam \& Pearson 2012; Wells 2007; online database LKCNHM), and local people.

\section{DNA BARCODING OF PLANT MATERIALS}

DNA barcoding analysis was used only for identifying plant materials (IS and FPM) due to the difficulty of identifying the samples to family or genus level. Seed samples were chosen from the different stomach and fecal samples to cover the whole sampling period and the diversity of the AGS diet. Genomic DNA was extracted from $50-100 \mathrm{mg}$ of fresh or frozen plant tissue using HiYield Genomic DNA Mini Kit (Plant) (Real Biotech Corporation, USA), according to the manufacturer's protocols.

Two DNA barcode markers were used: A plastid chloroplast $r b c L$ gene and nuclear ribosomal DNA internal transcribed spacer 2 (ITS2). $r b c L$ is a widely used universal primer with high variation and identification capability (Kress et al. 2007, 2005; Lahaye et al. 2008). This marker has high success in the amplification and sequencing steps and is appropriate for examining degraded material. ITS2 is a new universal barcode for identifying a wide range of plant taxa (Chen et al. 2010). This marker has been widely used for identifying medicinal plants due to its higher taxonomic resolution (Chen et al. 2010; Yao et al. 2010). For PCR amplification of $r b c L$, the primer combination used was 1F: 5'-ATG TCA CCA CAA ACA GAG ACT AAA GC-3' (Fay et al. 1997) and 724R: 5'-TCG CAT GTA CCT GCA GTA GC-3' (Kress et al. 2009). For ITS2, the primer combination was ITS2F: 5'- ATGCGATACTTGGTGTGAAT-3' (Chen et al. 2010) and ITS3R: 5'- GACGCTTCTCCAGACTACAAT-3' (Chen et al. 2010).

PCR amplification was performed in a total volume of $50 \mu \mathrm{L}$ consisting of $25 \mu \mathrm{L}$ EconoTaq PLUS GREEN 2X Master Mix (Lucigen, Middleton, WI, USA), 1.5 $\mu \mathrm{L}$ of each forward and reverse primer $(100 \mu \mathrm{M}), 20 \mu \mathrm{L}$ of $\mathrm{ddH}_{2} \mathrm{O}$ and $2 \mu \mathrm{L}$ of DNA. After an initial denaturing step for $r b c L$ at $95{ }^{\circ} \mathrm{C}$ for $4 \mathrm{~min}$, amplification proceeded for 30 cycles at $94{ }^{\circ} \mathrm{C}$ for $30 \mathrm{~s}, 52^{\circ} \mathrm{C}$ for $1 \mathrm{~min}, 72^{\circ} \mathrm{C}$ for $1 \mathrm{~min}$ (30 cycles); and a final extension at $72{ }^{\circ} \mathrm{C}$ for 10 min. PCR amplification protocols for ITS2 was: initial denaturation at $94{ }^{\circ} \mathrm{C}$ for $5 \mathrm{~min}$, denaturation, annealing, and extension at $72{ }^{\circ} \mathrm{C}$ for $10 \mathrm{~min}$. PCR products were checked on $2 \%$ agarose gel for the presence of DNA, and sent to MyTACG Bioenterprise (Malaysia) for purification and Sanger sequencing in both directions.

The $r b c L$ and ITS2 sequences were assembled and edited using Mega 7. The sequences for both markers were BLASTed against registered reference sequences in GenBank (https://blast.ncbi.nlm.nih.gov/Blast.cgi) to assign taxonomic names to each sample (Altschul et al. 1990; Huang et al. 2015; Lim et al. 2018). The identification of taxonomic names was accepted for sequences matched with $99 \%$ similarity with high query coverage in the reference data set (Bruni et al. 2015). Taxonomic names were assigned to matched sequences following the criteria mentioned in Lim et al. (2018): Species name was assigned to sequences matched with records from one species only; genus name was assigned to sequences matched with records from more than one species of the same genus; and family name was assigned to sequences matched with records from more than one genus in the same family. A sequence was unidentifiable when more than one matched species identity had less than $99 \%$ similarity. The analysis was performed separately for both markers, and the results were combined in the final identification up to species/ genus/family level of plant species found in the stomach and fecal samples of AGS. The assigned taxonomic names were crosschecked with several references for the status, distribution, morphological descriptions, and flowering and fruiting phenology (Chin \& Enoch 1988; Corner 1988; Kiew et al. 2010; Mat-Salleh \& Latiff 2002). 


\section{RESULTS}

Stereomicroscopic analysis of both samples (34 samples of stomach contents and 159 samples of droppings) showed that plant materials were present in $76 \%$ of the samples compared to animal materials in only $6 \%$ of the samples. A high number of intact seeds (IS) were found in most samples (53\%, 103 samples), especially in droppings. A mixture of animal and plant materials was more common in stomach contents $(21 \%)$ compared to in droppings (18\%). Overall, the proportion of animal material was low in both samples $(12 \%$ in stomach contents and 4\% in droppings). In total, 1518 IS were found in both samples and were sorted into 13 groups based on their morphological similarities. Initial morphological identification of a few samples suggested that the seeds were from the families Fabaceae, Vitaceae, Arecaceae, and Myristicaceae. A few fibers or fruit skins found in FPM appeared to be from the family Moraceae (figs).

In samples containing animal material, only snails $(15 \%)$ and ants $(6 \%)$ were found in stomach contents (Figure 2). These groups were detected in both samplings (March and April), with most fragments (54\%) found in March (Figure 2). In the dropping's samples, fragments of beetles (5\%) and snails (5\%) were the most prevalent animal material, followed by ants $(2 \%)$. Beetle fragments were detected in most samples except those collected in October 2016 and February and March 2017. The highest proportion of beetles were detected in December 2016 (7\%) and January (11\%) and April 2017 (14\%) as illustrated in Figure 3. Snail fragments were present in most samples except in those collected in July and December 2016 and February 2017. Snails were most common from August to October 2016 (7-21\%). Ant fragments were low in most months except in July and September 2016. The highest presence of ants (4\%) was in March 2017 (Figure 3).

Identification of animal fragments was only possible when morphological features were recognizable. In this context, only ants, a few samples of snails, and one sample of beetles were successfully identified. Other fragments of beetles and snails were excluded from the identification. Ants (family Formicidae) were successfully identified up to genus or species level (Table 1) for subfamilies Formicinae (Camponotus sp. and Oecophylla smaragdina) and Myrmicinae (Crematogaster sp. and Tetramorium sp.). Oecophylla smaragdina and Camponotus sp. were common in the diet of AGS, followed by Tetramorium sp. and Crematogaster sp. Oecophylla smaragdina was detected in both sample types with the highest percentage of occurrence recorded in stomach contents (40\%). Crematogaster sp. occurred only in the stomach contents of AGS and was found as a small proportion (5\%), while Camponotus sp. (59\%) and Tetramorium sp. (22\%) were detected only in droppings. Only one beetle sample was

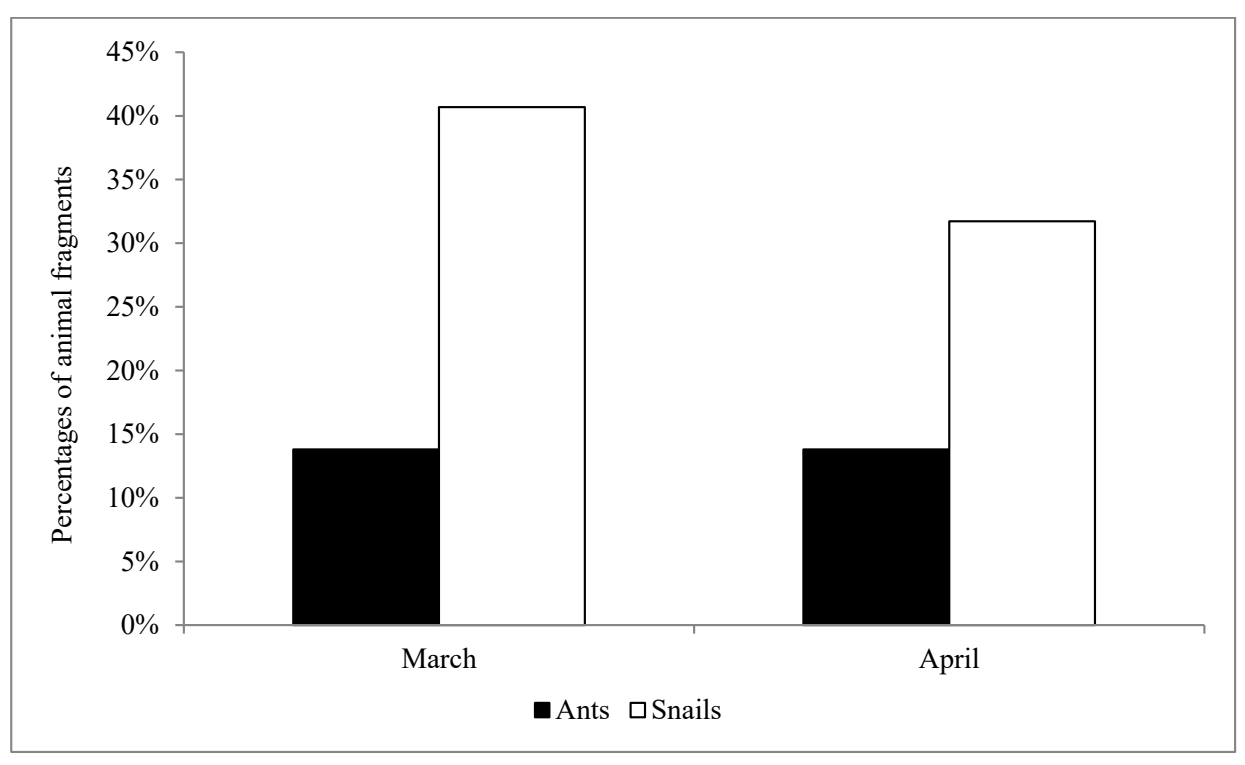

FIGURE 2. Percentages of animal fragments found in samples of stomach contents of the Asian glossy starling Aplonis panayensis. The samples were collected in March and April 2016 


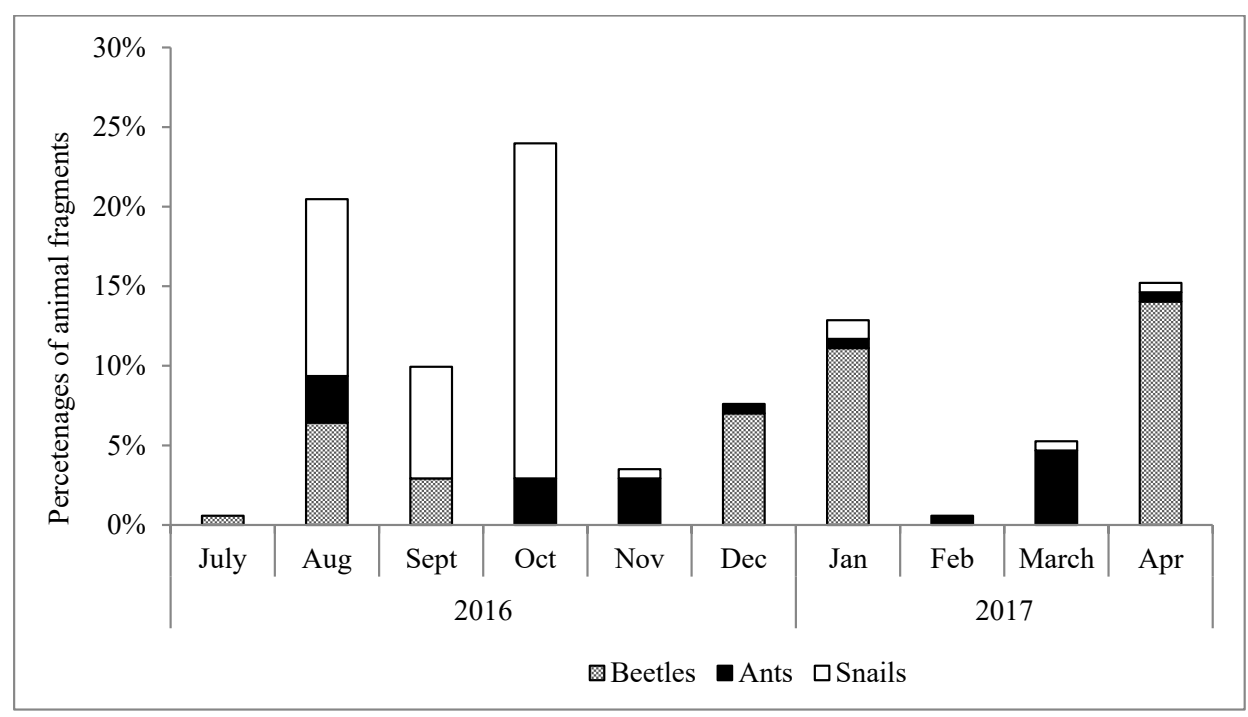

FIGURE 3. Percentages of animal fragments found in droppings of the Asian glossy starling Aplonis panayensis. The samples were collected during ten months of sampling (July 2016 to April 2017)

successfully identified, i.e. larvae of the Tenebrionidae. The long and slender segmented body of the larvae was found in four samples of droppings, and consisted of 10 to 12 individuals per sample.

Three species of snails were identified based on their morphological characteristics such as the number of whorls, shape and color of the shell, type of apex (sharp or blunt), and the shape of the peristome on the aperture (Table 1). Two land snail species, Subulina octona (Achatinidae) and Bradybaena similaris (Bradybaenidae), and a freshwater snail species, Physella acuta (Physidae), were identified. Of the three snail species, $S$. octona had the highest representation with eight individuals, while only one individual each of the other two species was present.

\section{DNA BARCODING OF INTACT SEEDS}

DNA was extracted from 23 samples of IS, and the amplification process was successful with no occurrence of non-specific bands. A total of 23 successful sequences were produced using the $r b c L$ primer; they were mostly uniform in size, ranging from 681 to $700 \mathrm{bp}$. For ITS2 markers, one sample from IS group 3 failed to produce ITS2 barcodes. In most samples, ITS2 sequences showed slight variation in length, ranging from 441 to $485 \mathrm{bp}$, except in one sample from seed group 8 , which produced short sequences of $283 \mathrm{bp}$. Identification of species using the sequences for both markers, compared to the dataset in GenBank, gave similar results for most IS groups except for groups 3 and 10 (Table 2).

The BLAST analysis of $r b c L$ sequences for most IS groups showed high similarity with one or two species names for the same genus, except for IS group 10, which showed high similarity to species from two different genera, Miconia chartacea and Stryphnodendron moricolor. Similar identification results were queried in BLAST analysis of ITS2 sequences from most IS groups except for groups 3 and 10. A successful ITS2 sequence from IS group 3 was $98 \%$ matched with one single species, Bridelia tomentosa. The ITS2 sequences of IS group 10 showed high similarity to two different species, Clidemia octona and Daucus carota.

Overall, both markers generated from 13 IS groups resulted in the identification of nine plant species (Table 2). One species name, Acacia mangium, was assigned to IS groups 1, 3, 6, and 7 based on high similarity of identification for both markers in GenBank. The decision made for the final identification of IS group 3 and one sample of IS group 7 was based on $r b c L$ sequences matched $\geq 99 \%$ with $A$. mangium. One species name was assigned to IS groups $5,9,11,12$, and 13 , which were $\geq 99 \%$ matched with a single species name in GenBank. IS group 9 was identified as Ficus benjamina. 
TABLE 1. Diet analysis of stomach contents and droppings of Asian glossy starling

\begin{tabular}{|c|c|c|c|}
\hline \multirow{2}{*}{ Categories } & \multirow{2}{*}{ Genus or species identification } & \multicolumn{2}{|l|}{ Relative abundance } \\
\hline & & Stomach contents & Droppings \\
\hline \multirow{3}{*}{ Ants } & Camponotus sp. & & 0.59 \\
\hline & Crematogaster sp. & 0.05 & \\
\hline & Oecophylla smaragdina & 0.4 & 0.19 \\
\hline \multirow{3}{*}{ Beetles } & Tetramorium sp. & & 0.22 \\
\hline & Tenebrionidae (larvae) & & 0.32 \\
\hline & Subulina octona & & 0.2 \\
\hline \multirow{4}{*}{ Snails } & Bradybaena similaris & & 0.05 \\
\hline & Physella acuta & & 0.05 \\
\hline & Acacia mangium & 0.56 & 0.01 \\
\hline & Acacia sp. & & 0.03 \\
\hline \multirow[t]{7}{*}{ Intact seeds } & Carica papaya & & 0.01 \\
\hline & Eleusina indica & & 0.01 \\
\hline & Ficus benjamina & & 0.6 \\
\hline & Glochidion sp. & & 0.01 \\
\hline & Paspalum conjugatum & & 0.01 \\
\hline & Pericampylus glaucus & 0.08 & \\
\hline & Trema orientalis & 0.36 & 0.32 \\
\hline
\end{tabular}

The seed samples were crosschecked with references and botany experts, and group 9 resembled $F$. benjamina seed rather than $F$. microcarpa. The final identification of IS groups 2 (Glochidion sp.) and 8 (Acacia sp.) was only to genus level due to the differences between $r b c L$ and ITS2 in identifying the same genus to species level (Table 2). Seeds in group 10 were unidentified due to the sequences from the two markers being matched to two different genera (Table 2).

\section{DIETARY VARIATION IN AGS}

Of the nine plant species identified through DNA barcoding, two species, F. benjamina and Carica papaya, were mentioned in the literature as forming a part of the diet of AGS. The other seven plant species identified in this study are new records for the AGS diet. Three out of the nine plant species were found in stomach contents. One species, Pericampylus glaucus (Menispermaceae), was found exclusively in stomach contents (Figure 4). However, the seeds of $P$. glaucus were detected only once (13\%) in April 2016 and consumed by only two out of 17 AGS individuals (12\%). All three plant species were detected in April 2016 at a higher percentage of seeds (62\%). Acacia mangium (Fabaceae) was the main plant species found in the stomach contents of AGS, followed by $36 \%$ of Trema orientalis (Ulmaceae). Both species were detected in both samplings. In March, 29\% of the AGS individuals had eaten A. mangium; this had slightly decreased to $18 \%$ in April. Trema orientalis was consumed by $18 \%$ of the birds in March, and this increased to $29 \%$ in April (Figure 4). 
TABLE 2. Identification of intact seeds (IS) found in stomach contents and droppings of Asian glossy starling (Aplonis panayensis) using DNA barcoding

\begin{tabular}{|c|c|c|c|}
\hline \multirow{2}{*}{$\begin{array}{l}\text { IS } \\
\text { group }\end{array}$} & \multicolumn{2}{|c|}{ DNA barcoding identification using two markers $\left({ }^{a}\right)$} & \multirow{2}{*}{ Final identification } \\
\hline & $r b c L$ & ITS2 & \\
\hline \multirow{2}{*}{1} & Acacia mangium $(100 \%)$ & Acacia mangium $(100 \%)$ & Acacia mangium \\
\hline & Acacia mangium $(100 \%)$ & Acacia mangium (99\%) & Acacia mangium \\
\hline \multirow{2}{*}{2} & Glochidion eriocarpum (100\%) & Glochidion lanceolarium (99\%) & Glochidion sp. \\
\hline & Glochidion eriocarpum (100\%) & Glochidion lanceolarium (99\%) & Glochidion sp. \\
\hline \multirow{2}{*}{3} & Acacia mangium $(100 \%)$ & Failed & Acacia mangium $^{\mathrm{b}}$ \\
\hline & Acacia mangium $(99 \%)$ & Bridelia tomentosa $(98 \%)$ & Acacia mangium $^{\mathrm{b}}$ \\
\hline \multirow{2}{*}{4} & Trema orientalis $(100 \%)$ & Trema orientalis $(100 \%)$ & Trema orientalis \\
\hline & Trema orientalis $(100 \%)$ & Trema orientalis $(100 \%)$ & Trema orientalis \\
\hline \multirow{2}{*}{5} & Pericampylus glaucus $(100 \%)$ & Pericampylus glaucus $(99 \%)$ & Pericampylus glaucus \\
\hline & Pericampylus glaucus $(100 \%)$ & Pericampylus glaucus (99\%) & Pericampylus glaucus \\
\hline \multirow{2}{*}{6} & Acacia mangium $(100 \%)$ & Acacia mangium $(100 \%)$ & Acacia mangium \\
\hline & Acacia mangium $(100 \%)$ & Acacia mangium $(100 \%)$ & Acacia mangium \\
\hline \multirow{2}{*}{7} & Acacia mangium $(100 \%)$ & Acacia mangium $(99 \%)$ & Acacia mangium \\
\hline & Acacia mangium $(100 \%)$ & Acacia mangium $(96 \%)$ & Acacia mangium $^{\mathrm{b}}$ \\
\hline \multirow{2}{*}{8} & Acacia mangium $(100 \%)$ & Acacia spirorbis $(99 \%)$ & Acacia $\mathrm{sp}$ \\
\hline & Acacia mangium $(100 \%)$ & Acacia spirorbis $(99 \%)$ & Acacia sp. \\
\hline \multirow{2}{*}{9} & Ficus microcarpa $(100 \%)$ & Ficus benjamina $(99 \%)$ & Ficus benjamina \\
\hline & Ficus benjamina $(100 \%)$ & Ficus benjamina $(99 \%)$ & Ficus benjamina \\
\hline \multirow{2}{*}{10} & Miconia chartacea $(99 \%)$ & Clidemia octona $(99 \%)$ & unidentified \\
\hline & Stryphnodendron moricolor (97\%) & Daucus carota $(100 \%)$ & unidentified \\
\hline 11 & Paspalum conjugatum (99\%) & Paspalum conjugatum $(100 \%)$ & Paspalum conjugatum \\
\hline 12 & Eleusina indica $(100 \%)$ & Eleusina indica $(100 \%)$ & Eleusina indica \\
\hline 13 & Carica papaya $(100 \%)$ & Carica papaya $(100 \%)$ & Carica papaya \\
\hline
\end{tabular}

aPercentages of matched identity with GenBank

${ }^{b}$ Final identification of seed group 3 based on succeeding $r b c L$ sequences

Eight plant species were detected in the droppings (Figure 5). Two plant species, T. orientalis and A. mangium, found in stomach contents samples were also detected in the droppings. Two plant species, $F$. benjamina (69\%) and T. orientalis (23\%), dominated the diet of AGS. Trema orientalis was commonly eaten in most months except for January 2017. The number of AGSs feeding on the plant was higher in 2016 (Figure 6) and decreased towards the end of sampling (a mean of seven birds per sampling). Although the percentage of
F. benjamina seeds in the diet was the highest, few AGSs consumed this species in July, January, and April 2017 (a mean of three birds per sampling). Only three species were collected once in 11 samplings (Figure 6), with small numbers of seeds: Carica papaya (one seed from one bird), Eleusine indica (four seeds from four birds), and Paspalum conjugatum (two seeds from one bird). One to four plant species were present in each of the 11 samplings with a mean of 148 seeds per sampling. 


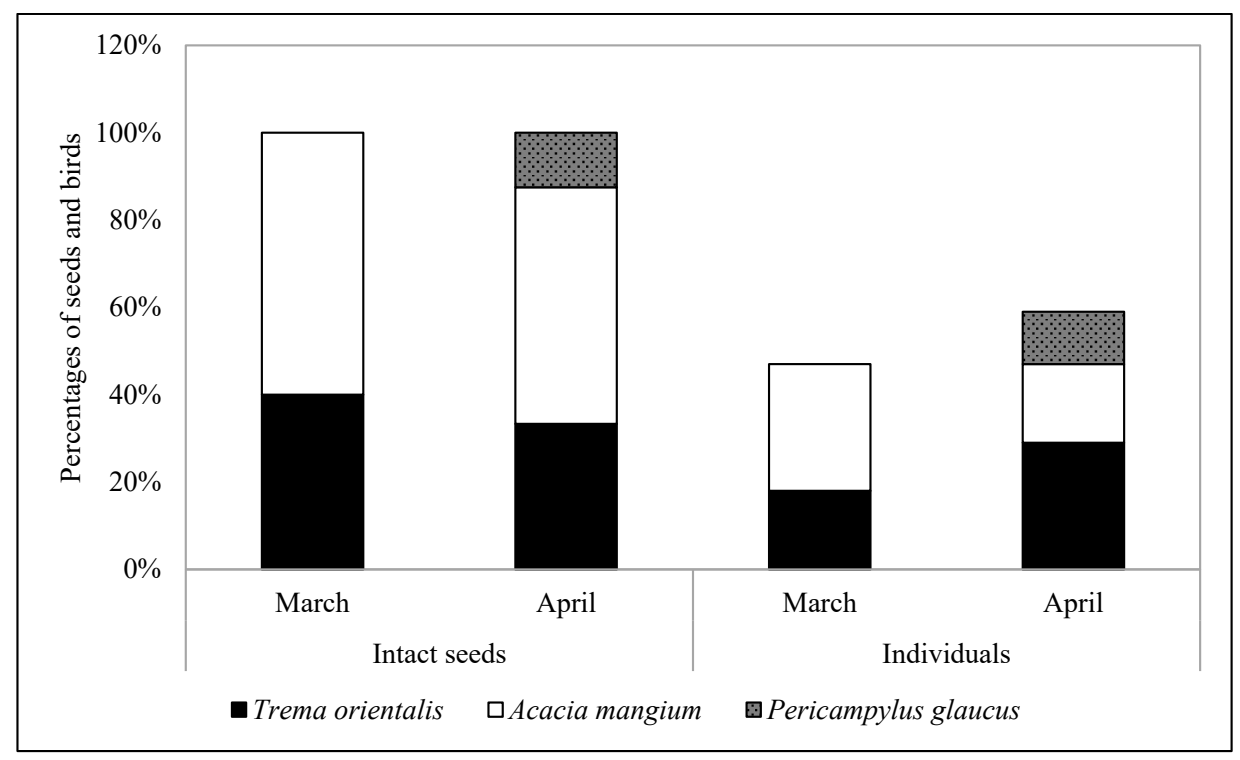

FIGURE 4. Percentages of intact seeds (IS) of three plant species found in stomach contents of Asian glossy starling Aplonis panayensis

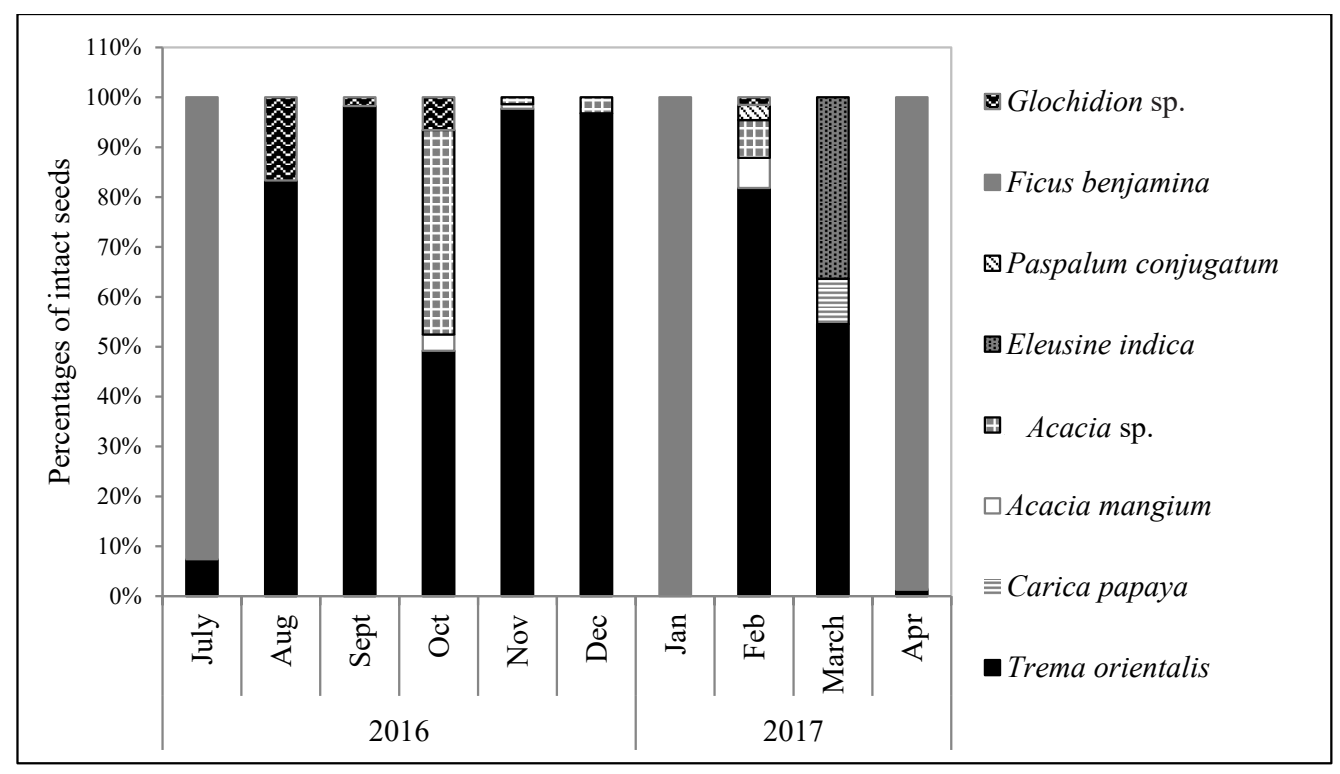

FIGURE 5. Percentages of intact seeds (IS) of eight plant species detected in the droppings of the Asian glossy starling Aplonis panayensis

\section{DISCUSSION}

Stereomicroscopic analysis of the samples of stomach contents and droppings showed that the diet of AGS consisted mainly of fruits with a small component of invertebrates. Generally, starlings are considered omnivores that include both plant and animal materials in their diet (Feare 1984; Martin 1986; Wells 2007). Starlings cannot digest cellulose; hence they eat seeds and fruit, which contain readily digestible carbohydrates and small amounts of protein and lipid (Feare 1984). The 


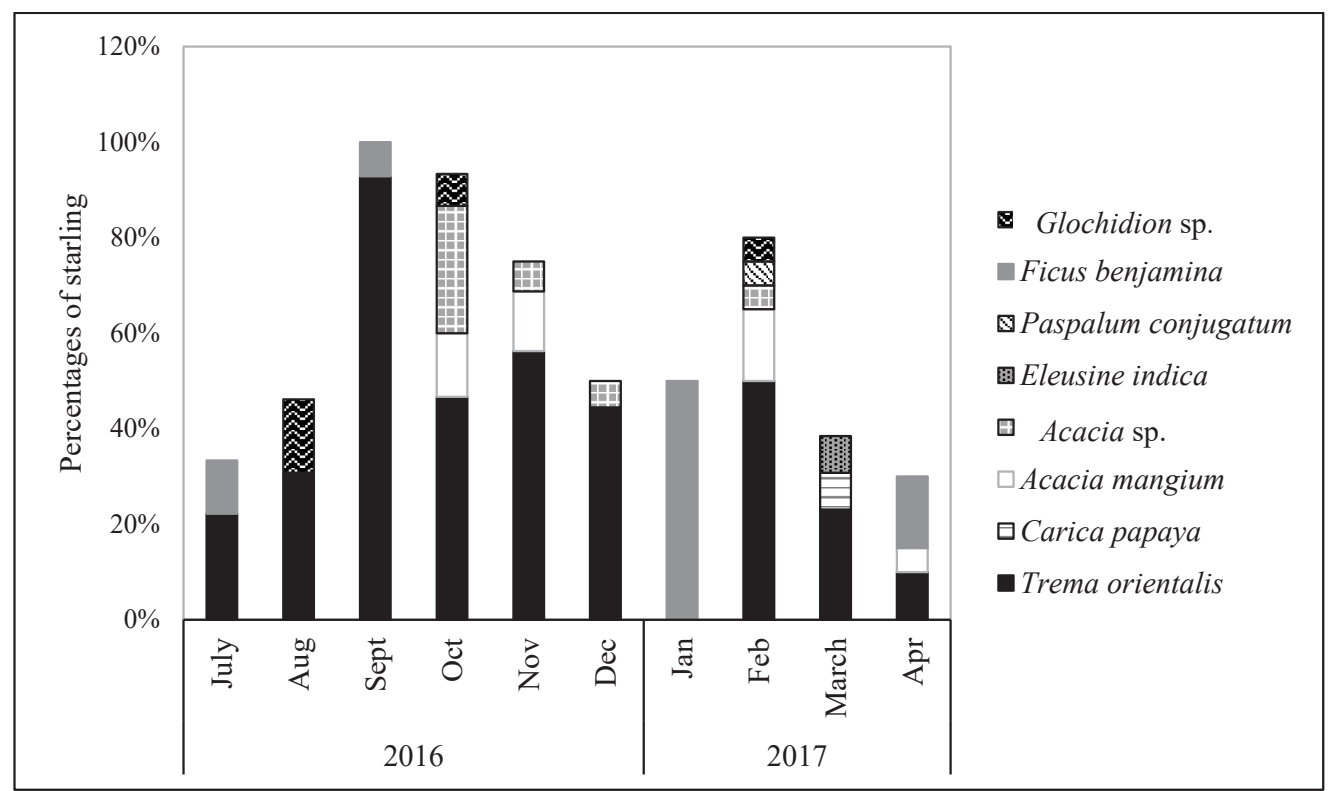

FIGURE 6. Percentages of Asian glossy starling Aplonis panayensis that consumed intact seeds (IS) of the eight plant species detected in droppings. The plants were identified through DNA barcoding of samples collected over ten months (July 2016 to April 2017) at roosting sites at the Universiti Malaya Biotechnology Research Centre, Jelebu, Negeri Sembilan

undigested seeds pass through the gut and are excreted later (Khan \& Ahsan 2015). Frugivorous birds can facilitate seed germination either away from the parental plants or within the same area, depending on passage rates (Khan \& Ahsan 2015; LaFleur et al. 2009). The size of fruits that can be swallowed by starlings is limited by the size of bill and gape (Feare 1984). Starlings will break down the soft flesh of large fruits before swallowing it (Feare 1984). In this study, most seeds found in both sample types were minute (0.1-0.5 cm in width and length). The variety of fruits consumed by AGS was apparent in the different texture, shape, color, and size of the seeds as well as the fragmented plant materials.

Seed identification was difficult with incomplete plant structures such as inflorescences and infructescence (Cappers \& Bekker 2013; Kamaruddin 2005). In addition, information on the plant's family is needed before further identification of seed and fruit structures (Cappers \& Bekker 2013). In this study, the problem of identifying IS was overcome by applying the DNA barcoding method. Although few samples were used for DNA barcoding, nine plant species were successfully detected in the IS samples, with seven new plant records for the AGS diet. Most of the IS samples used in DNA barcoding were successfully identified to species level by using two markers, $r b c L$ and ITS2. However, one IS group (i.e. group 10) could not be assigned to specific names, probably due to contamination of the samples.

Frugivorous birds like AGS generally prefer carbohydrate-rich foods such as berries and figs (Wells 2007). This is consistent with our finding that the AGS diet mainly consisted of berries (T. orientalis, P. glaucus, and Glochidion sp.) and figs (F. benjamina). These types of fruits are easy to digest and their nutrients are readily absorbed (Kinnaird \& O’Brien 1992). AGS also consumed lipid-rich fruits such as the pod fruits of Acacia sp. and Acacia mangium which can provide higherquality energy sources compared to berries and figs. However, this type of fruit may take longer to process before absorption of nutrients compared to carbohydraterich fruits (Kinnaird \& O’Brien 1992).

In this study, the plants consumed by AGS were mostly fast-growing pioneer tree species commonly found at forest edges and roadsides or in open areas or villages. The fruits consumed by AGS are available yearround but the variation in the diet could be influenced by the fruiting season of each species (Corner 1988; Kiew et al. 2010). Fluctuations in the population size of roosting AGS may be influenced by food availability close to the roosting area. For instance, the most consumed species 
T. orientalis grew extensively along the roadside within the foraging range and daytime resting places of AGS. As shown for the European starling, movement and size of home range could be affected by the availability of high-quality foraging habitats and food resources (Minderman et al. 2010). The movement could be extended for better foraging areas, or the starlings might leave the roosting area for another whenever food resources become unavailable (Feare 1984; Minderman et al. 2010). However, this species also has the flexibility to switch its diet to another similar type of fruit available within its range (Feare 1984).

In addition to fruits, a small proportion of invertebrates, consisting of ants, snails, and beetles, were found in both samples. Ants are social insects that maintain a perennial nest (Agosti et al. 2000). Ants may build nests in hollow trees such as Camponotus and Crematogaster species (Agosti et al. 2000), or underneath leaves like Oecophylla smaragdina (Devarajan 2016) or in decaying wood, leaf litter, or directly in the soil alike Tetramorium sp. (Bolton 1980). In this study, $O$. smaragdina was found in most AGS stomach contents and droppings samples. This Asian weaver ant builds its nests by weaving together leaves of the host plant using the silk produced by their larvae (Devarajan 2016).

Ants are accessible to vertebrates such as birds while feeding on trees due to their permanent nests, large numbers, and foraging behavior (Agosti et al. 2000). Ants could potentially be eaten by frugivorous birds, particularly starlings, while feeding on fruits. In this study, ants were mostly found together with plant materials from species such as T. orientalis, A. mangium, and Glochidion sp. In addition, AGS individuals were seen to forage for insects on branches, leaves, and flowers of Bauhinia purpurea, Caesalpinia pulcherrima, and Leucaena leucocephala at the roosting area during preroosting. However, IS of these species were not detected in the stomach contents and droppings of AGS. Besides serving as the last feeding ground for AGS, these trees also functioned as preferred pre-roosting sites for AGS. Pruning and cutting of these trees has been one of practical methods by the management of the research centre to control the population of roosting AGS.

In the study area, small numbers of AGS were seen joining mixed feeding groups with mynas on the ground. This feeding activity could explain the presence of insects, such as beetle larvae and snails in the diet. AGS consumed Tenebrionidae larvae, which are commonly found deposited in soils (Watt 1974). The larvae are elateroid (wireworm-like) or C-shaped, and are called false wireworms due to their resemblance to the larvae of the Elateridae (Triplehorn 2008). They are considered agricultural pests due to the damage caused to the belowground parts of plants, such as stems and roots, and seeds (Smith et al. 2013; Triplehorn 2008).

In addition, three snail species, Subulina octona, Bradybaena similaris, and Physella acuta, were detected in the diet of AGS. This finding is a new record of snail species in the diet of AGS besides the Hemiplecta snails mentioned by Wells (2007). Subulina octona and B. similaris are tropical land snails commonly found in urban and suburban habitats (Foon et al. 2017). Physella acuta is a freshwater snail usually found in modified freshwater habitats such as dams, ponds, streams, reservoirs, and canals ( $\mathrm{Ng}$ et al. 2015). Subulina octona is commonly found in groups, which may explain why AGS ate more of them compared to the other two species. AGS probably consumed land snails while foraging on the ground. The presence of the freshwater snail $P$. acuta suggests that AGS also forages in aquatic areas. In the study area, there are lakes and ponds near the roosting sites, which could be potential foraging sites for AGS. Consumption of insects and snails by AGS could complement the fruit diet as both food types contain high amounts of protein, calcium, iron, fats, dietary fibers, other minerals, and vitamins (Fagbuaro et al. 2006; Kourimska \& Adamkova 2016). Animal prey in the diet probably depends on their availability at the foraging sites rather than being an attempt to balance daily nutritional requirements.

\section{CONCLUSION}

Our study is the first to describe in detail the diet of AGS through microscopic analysis and DNA barcoding using stomach contents and droppings. An assessment of the diet of this urban bird is essential for determining factors influencing its communal roosting activity. The abundance of food resources within range of the roosting area appeared to be one of the key factors for roosting site fidelity of AGS in the study area. The flexibility of this generalist bird in consuming many types of fruit is likely to allow it to switch its diet based on availability. Seven of the plant species identified in this study are new records of plants in the diet of AGS. Although the fruits consumed were not within the immediate vicinity of the roosting sites, pruning and cutting down a few trees that served as the last feeding sites en route to the roost was a useful management practice to reduce the number nuisance birds. The consumption of land and freshwater snails, ants, and larvae of the Tenebrionidae 
could supplement the fruit diet of AGS. The technique of DNA barcoding may be enhanced in the future by using next-generation sequencing to identify mass samples of intact seeds and plant fragments.

\section{ACKNOWLEDGEMENTS}

We would like to extend our gratitude to the management of the Universiti Malaya Biotechnology Research Centre, Glami Lemi (PPBGL), Jelebu, Negeri Sembilan for allowing us to conduct this research. Our gratitude also goes to the staff of PPBGL and Institute of Biological Sciences, Faculty of Sciences, Universiti Malaya, Kuala Lumpur, Malaysia, who have assisted us in the field. We also thank the experts (Mohammad Effendi Marzuki, Jun Kitt Foon, Muhammad Firdaus Abdullah Sani) that helped us in the morphological identification of plant and animal samples collected. This work was supported by Universiti Malaya Research Grant (Grant number: RP015D-14AFR) and Postgraduate Research Grant (PG204-2015A).

\section{REFERENCES}

Agosti, D., Majer, J., Alonso, E. \& Schultz, T.R. 2000. Ants: Standard Methods for Measuring and Monitoring Biodiversity. Washington, DC: Smithsonian Institution Press.

Altschul, S.F., Gish, W., Miller, W., Myers, E.W. \& Lipman, D.J. 1990. Basic local alignment search tool. Journal of Molecular Biology 215(3): 403-410.

Aziz, N.A.A., Ahmad, M.I. \& Naim, D.M. 2015. Molecular DNA identification of medicinal plants used by traditional healers in Malaysia. Genetics and Molecular Research 14(4): 15937-15947.

Aziz, S.A., Clements, G.R., Peng, L.Y., Campos-Arceiz, A., McConkey, K.R., Forget, P.M. \& Gan, H.M. 2017. Elucidating the diet of the island flying fox (Pteropus hypomelanus) in Peninsular Malaysia through illumina next-generation sequencing. Peer J. 5: e3176.

Bolton, B. 1980. The ant tribe Tetramoriini. The genus Tetramorium Mayr in the Ethiopian zoogeographical region. Bulletin of the British Museum (Natural History), Entomology 40: 193-384.

Brook, B.W., Sodhi, N.S., Soh, M.C.K. \& Lim, H.C. 2003. Abundance and projected control of invasive house crows in Singapore. Journal of Wildlife Management 67(4): 808817.

Bruni, I., Galimberti, A., Caridi, L., Scaccabarozzi, D., De Mattia, F., Casiraghi, M. \& Labra, M. 2015. A DNA barcoding approach to identify plant species in multiflower honey. Food Chemistry 170: 308-315.

Cappers, R. \& Bekker, R. 2013. A Manual for the Identification of Plant Seeds and Fruits. Groningen: Barkhuis.
Chen, S., Yao, H., Han, J., Liu, C., Song, J., Shi, L., Zhu, Y., Ma, T.G., Pang, X., Luo, K., Li, Y., Li, X., Jia, X., Lin, Y. \& Leon, C. 2010. Validation of the ITS2 region as a novel DNA barcode for identifying medicinal plant species. PLoS ONE 5(1): e8613.

Chin, H.F. \& Enoch, I.V. 1988. Malaysian Trees in Colour. Kuala Lumpur: Tropical Press Sdn. Bhd.

Corner, E.J.H. 1988. Wayside Trees of Malaya. (Vols. 1-2). Kuala Lumpur. The Malayan Nature Society.

Devarajan, K. 2016. Correction: The antsy social network: Determinants of nest structure and arrangement in Asian Weaver Ants. PLoS ONE 11(7): e0159284.

Fagbuaro, O., Oso, J.A., Edward, J.B. \& Ogunleye, R.F. 2006. Nutritional status of four species of giant land snails in Nigeria. Journal of Zhejiang University SCIENCE B 7(9): 686-689.

Fay, M.F., Swensen, S.M. \& Chase, M.W. 1997. Taxonomic affinities of Medusagyne oppositifolia (Medusagynaceae). Kew Bulletin 52: 111-120.

Feare, C. 1984. The Starling. Oxford: Oxford University Press.

Feare, C. \& Craig, A. 1999. Starlings and Mynas (Helm Identification Guide). New Jersey: Princeton University Press.

Fernandez-Juricic, E., Siller, S. \& Kacelnik, A. 2004. Flock density, social foraging, and scanning: An experiment with starlings. Behavioral Ecology 15(3): 371-379.

Fischl, J. \& Caccamise, D.F. 1987. Relationship of diet and roosting behaviour in the European Starling. American Midland Naturalist 117(2): 395-404.

Foon, J.K., Clements, G.R. \& Liew, T.S. 2017. Diversity and biogeography of land snails (Mollusca, Gastropoda) in the limestone hills of Perak, Peninsular Malaysia. ZooKeys 682: 1-94.

Galimberti, A., Spinelli, S., Bruno, A., Mezzasalma, V., DeMattia, F., Cortis, P. \& Labra, M. 2016. Evaluating the efficacy of restoration plantings through DNA barcoding of frugivorous bird diets. Conservation Biology 30(4): 763-773.

Hashimoto, Y. 2003. Identification guide to the ant genera of Borneo. In Inventory and Collection, edited by Hashimoto, Y. \& Rahman, H. UMS-BBEC Press. pp. 95-160.

Huang, X-C., Ci, X-Q., Conran, J.G. \& Li, J. 2015. Application of DNA barcodes in Asian tropical trees - A case study from Xishuangbanna Nature Reserve, Southwest China. PLoS ONE 10(6): e0129295.

Jeyarajasingam, A. \& Pearson, A. 2012. A Field Guide to the Birds of Peninsular Malaysia and Singapore. Oxford: Oxford University Press.

Kamaruddin, K. 2005. Mengenal Pokok Tempatan. Kuala Lumpur: Dewan Bahasa dan Pustaka.

Khan, S.I. \& Ahsan, M.F. 2015. Frugivorous birds and fruit plants in a deciduous forest in Bangladesh: A case study in the Madhupur National Park. Bangladesh Journal of Zoology 43(2): 173-187.

Kiew, R., Chung, R.C.K., Saw, L.G., Soepadmo, E. \& Boyce, P.C. 2010. Flora of Peninsular Malaysia. Series II: Seed Plants. Volume 1. Selangor: Forest Research Institute Malaysia. 
Kinnaird, M.F. \& O’Brien, T.G. 1992. The Ecology and Conservation of Asian Hornbills. London: The University of Chicago Press.

Kouřimská, L. \& Adámková, A. 2016. Nutritional and sensory quality of edible insects. NFS Journal 4: 22-26.

Kress, W.J. \& Erickson, D.L. 2007. A two-locus global DNA barcode for land plants: The coding $r b c L$ gene complements the non-coding trnH-psbA spacer region. $P L o S$ ONE 2(6): e508.

Kress, W.J., Garcia-Robledo, C., Uriarte, M. \& Erickson, D.L. 2015. DNA barcodes for ecology, evolution, and conservation. Trends in Ecology and Evolution 30: 25-35.

Kress, W.J., Erickson, D.L., Jones, F.B., Nathan, G., Swenson, N.G., Rolando Perez, R., Oris Sanjur, O. \& Eldredge Bermingham, E. 2009. Plant DNA barcodes and a community phylogeny of a tropical forest dynamics plot in Panama. Proceedings of the National Academy of Sciences of the United States of America 106(44): 18621-18626.

Kress, W.J., Wurdack, K.J., Zimmer, E.A.C., Weigt, L.A. \& Janzen, D.H. 2005. Use of DNA barcodes to identify flowering plants. Proceedings of National Academy of Sciences of the United States of America 102: 8369-8374.

LaFleur, N., Rubega, M. \& Jason Parent, J. 2009. Does frugivory by European Starlings (Sturnus vulgaris) facilitate germination in invasive plants? Journal of the Torrey Botanical Society 136(3): 332-341.

Lahaye, R., van der Bank, M., Bogarin, D., Warner, J., Pupulin, F., Gigot, G., Maurin, O., Duthoit, S., Barraclough, T.G. \& Savolainen, V. 2008 DNA barcoding the floras of biodiversity hotspots. Proceedings of National Academy of Sciences of the United States of America 105: 2923-2928.

Lee Kong Chian Natural History Museum 2019. The Biodiversity of Singapore. A Digital Reference Collection for Singapore's Biodiversity. https://singapore.biodiversity. online/species/A-Vert-Aves-000036.

Lim, H.C., Sodhi, N.S., Brook, B.W. \& Soh, M.C.K. 2003. Undesirable aliens: Factors determining the distribution of three invasive bird species in Singapore. Journal of Tropical Ecology 19(6): 685-695.

Lim, V-C., Ramli, R., Bhassu, S. \& Wilson, J.J. 2018. Pollination implications of the diverse diet of tropical nectar-feeding bats roosting in an urban cave. Peer J. 6: e4572.

Lim, V.C., Ramli, R., Bhassu, S. \& Wilson, J.J. 2017. A checklist of the bats of Peninsular Malaysia and progress towards a DNA barcode reference library. PLOS ONE 12(7): e0179555.

Linz, G.M., Johnson, R.J. \& Thiele, J. 2018. European Starlings. USDA National Wildlife Research Center-Staff Publications 2027.

Mansor, M.S., Nor, S.M. \& Ramli, R. 2018a. Assessing diet of the Rufous-Winged Philentoma (Philentoma pyrhoptera) in lowland tropical forest using Next-Generation Sequencing. Sains Malaysiana 47(5): 1045-1050.

Mansor, M.S., Abdullah, N.A., Halim, M.R.A., Nor, S.M. \& Ramli, R. 2018b. Diet of tropical insectivorous birds in lowland Malaysian rainforest. Journal of Natural History 52(35-36): 2301-2316.
Martin, G.R. 1986. The eye of a passeriform bird, the European starling (Sturnus vulgaris): eye movement amplitude, visual fields and schematic optics. Journal of Comparative Physiology A 159: 545-557.

Mat-Salleh, K. \& Latiff, A. 2002. Tumbuhan Ubatan Malaysia. Bangi: Universiti Kebangsaan Malaysia.

Minderman, J., Reid, J.M., Hughes, M., Denny, M.J.H., Hogg, S., Evans, P.G.H. \& Whittingham, M.J. 2010. Novel environment exploration and home range size in starlings Sturnus vulgaris. Behavioral Ecology 21(6): 1321-1329.

Morrison, D.W. \& Caccamise, D.F. 1985. Ephemeral roosts and stable patches? A radiotelemetry study of communally roosting starlings. Auk 102: 793-804.

Ng, F.S.P. 1991. Manual of Forest Fruits, Seeds and Seedlings. Vols. I and II. Kuala Lumpur: Forest Research Institute Malaysia.

Ng, T.H., Tan, S.K. \& Yeo, D.C.J. 2015. Clarifying the identity of the long-established, globally-invasive Physella acuta Draparnaud, 1805 (Gastropoda: Physidae) in Singapore. Bioinvasions Records 4: 189-194.

Peh, K.S.H. \& Sodhi, N.S. 2002. Characteristics of nocturnal roosts of house crows in Singapore. The Journal of Wildlife Management 66(4): 1128-1133.

Robson, C. 2008. Birds of South-East Asia. London: New Holland Publisher.

Rodway, M.S. \& Cooke, F. 2002. Use of fecal analysis to determine seasonal changes in the diet of wintering Harlequin Ducks at a herring spawning site. Journal of Field Ornithology 73(4): 363-371.

Shazali, N., Mohd-Azlan, J. \& Tuen, A.A. 2016. Bird diets in urban environments: The case of the Asian Glossy Starling, Aplonis panayensis. In Naturalists, Explorers and Field Scientists in South-East Asia and Australasia. Topics in Biodiversity and Conservation, 15, edited by Das, I. \& Tuen, A.A. Sarawak: Springer International Publishing.

Smith, A.D., Dornburg, R. \& Wheeler, D.D. 2013. Larvae of the genus Eleodes (Coleoptera, Tenebrionidae): Matrixbased descriptions, cladistic analysis, and key to late instar. ZooKeys 415: 217-268.

Soh, M.C.K., Sodhi, N.S., Seoh, R.K.H. \& Brook, B.W. 2002. Nest site selection of the house crow Corvus splendens, an urban invasive bird species in Singapore and implications for its management. Landscape Urban Planning 59: 217 226.

Sontag, W.A. \& Louette, M. 2007. The potential of particular starlings (Sturnidae) as indicators of habitat change. Journal of Ornithology 148(Suppl. 2): S261-S267.

Strange, M. \& Jeyarajasingam, A. 1993. Birds: A Photographic Guide to the Birds of Peninsular Malaysia and Singapore. Singapore: Sun Tree Publishing Pte Ltd.

Summers, R.W. \& Feare, C.J. 1995. Roost departure by European Starlings Sturnus vulgaris: Effects of competition and choice of feeding site. Journal of Avian Biology 26(4): 289-295.

Teng, B., Dao, S., Donaldson, Z.R. \& Grether, G.F. 2012. New communal roosting tradition established through experimental translocation in a Neotropical harvestman. Animal Behaviour 84: 1183-1190. 
Thiele, J.R., Linz, G.M., Homan, H.J. \& Unrein, G.W. 2012. Developing an effective management plan for starlings roosting in Downtown Omaha, Nebraska. USDA National Wildlife Research Center - Staff Publications 1196.

Triplehorn, C.A. 2008. Darkling Beetles (Coleoptera: Tenebrionidae). In Encyclopedia of Entomology, Volume 1, edited by Capinera, J.L. Dordrecht, Netherlands: Springer. pp. 1151-1153.

Ward, P. \& Zahavi, A. 1973. The importance of certain assemblages of birds as "information centers" for food finding. Ibis 115: 517-534.

Watt, J.C. 1974. A revised subfamily classification of Tenebrionidae (Coleoptera). New Zealand Journal of Zoology 1(4): 381-452.

Weatherhead, P.J. 1983. Two principal strategies in avian communal roosts. The American Naturalist 121(2): 237-243.

Wells, D.R. 2007. The Birds of the Thai-Malay Peninsula: Passerines. Vol. Two. London: Black Publisher Ltd.

Wilson, R.F., Sarim, D. \& Rahman, S. 2015. Factors influencing the distribution of the invasive house crow (Corvus splendens) in rural and urban landscapes. Urban Ecosystem 18: 1389-1400.

Yao, H., Song, J., Liu, C., Luo, K., Han, J., Li, Y., Pang, X., Xu, H., Zhu, Y., Xiao, P. \& Chen, S. 2010. Use of ITS2 region as the Universal DNA barcode for plants and animals. PLos ONE 5(10): e13102.
Yap, C.A.-M. \& Sodhi, N.S. 2004. Southeast Asian invasive birds: Ecology, impact and management. Ornithological Science 3: 57-67.

Yap, C.A.-M., Sodhi, N.S. \& Brook, B.W. 2002. Roost characteristics of invasive mynas in Singapore. The Journal of Wildlife Management 66(4): 1118-1127.

Noorul Ezyan Nor Hashim, Nurul Ashikin Abdullah \& Rosli Ramli*

Institute of Biological Sciences

Faculty of Science

Universiti Malaya

50603 Kuala Lumpur, Federal Territory

Malaysia.

Mohammad Saiful Mansor

Department of Biological Sciences and Biotechnology

Faculty of Science and Technology

Universiti Kebangsaan Malaysia

43600 UKM Bangi, Selangor Darul Ehsan

Malaysia

*Corresponding author; email: rosliramli@um.edu.my

Received: 16 July 2020

Accepted: 5 February 2021 